\title{
APPLICATION OF PHYSICALLY MODIFIED (ACTIVE) WATER FOR IMPROVING THE EFFICIENCY OF FOOD PRODUCTION TECHNOLOGIES AND IMPROVING QUALITY OF PRODUCTION
}

\author{
A. Ukrainets, Yu. Bolshak, R. Svyatnenko, Z. Prohorenko \\ National University of Food Technologies
}

\begin{tabular}{l} 
Key words: \\
Water \\
Living matter \\
Redox potential \\
\hline Article history: \\
Received 11.09.2018 \\
Received in revised form \\
02.10.2018 \\
Accepted 19.10.2018 \\
\hline
\end{tabular}

Corresponding author:

R. Svyatnenko

E-mail:

Svyatnenko@i.ua

\begin{abstract}
The quality of food products is related to the physiological quality of water, although the specifics of production impose their sectoral regulatory adjustments for the quality of water as a component of food products. The chemical and hygienic concept of "clean drinking water" is not identical. From the chemical point of view, the bestillytes approach the notion of absolutely pure water. But the hygienic approach defines such water as physiologically inferior.

The article reveals a special role of water, which is the structural and energy basis of living matter, not only in terms of providing the physiological value of drinking water, but also as an important factor in ensuring the quality of food products, the component of which water is practically always. The evolution of drinking water quality criteria from the indicators of its sanitary-chemical safety to the adoption of the notion of the physiological quality of drinking water as well as the influence of water on the quality of food products is considered. The advantage of water as a source of nutrient supplementation is shown.
\end{abstract}

A new approach to the purposeful change of physicochemical and biological properties of water through the nonreagent (physical) influence on water by various physical factors is considered. It is shown that in this case, without any changes in its chemical composition, physically modified water is capable for acquiring a new quasi non-equilibrium thermodynamic state associated with the accumulation of excess free energy by water molecules. At the expense of the latter, after the cessation of physical effects on water, work (including biological) can be performed in those media to which water enters. The feature of use of non-reagent modified (activated) water as a component of aqueous media in food technologies is shown. Numerous examples of the successful introduction of electrochemically activated water (anolyte and catholyte) in various branches of food production are presented, and the resulting technical and economic, ecological effect and quality improvement of products are given.

DOI: $10.24263 / 2225-2924-2018-24-5-27$ 


\title{
ЗАСТОСУВАННЯ ФІЗИЧНО ЗМІНЕНОÏ (АКТИВОВАНОÏ) ВОДИ ДЛЯ ПІДВИЩЕННЯ ЕФЕКТИВНОСТІ ТЕХНОЛОГІЙ ХАРЧОВОГО ВИРОБНИЦТВА ТА ПОЛІПШЕННЯ ЯКОСТІ ПРОДУКЦІї
}

\author{
А.І. Українець, Ю.В. Большак, Р.С. Святненко, Ж.І. Прохоренко \\ Національний університет харчових технологій
}

Якість харчових продуктів пов'язана з фізіологічною повноцінністю води, хоча специфіка виробництва накладає свої галузеві нормативні корективи щодо якості води як складової харчової продукиії. Хімічне та гігієнічне поняття «чиста питна вода» не тотожсні. 3 хімічного погляду бідистилят наближсається до уявлення про абсолютно чисту воду. Але гігієнічний підхід визначає таку воду як фізіологічно неповноцінну.

У статті розкривається особлива роль води, яка є структурно-енергетичною основою живої матерії, не тільки в плані забезпечення фізіологічної повноцінності питної води, але й як важливого фактора забезпечення якості харчової продукиії, компонентом якої вода є практично завжди. Розглянуто еволючію критеріїв якості питної води від показників ї̈ санітарно-хімічної безпеки до прийняття поняття фізіологічної повноцінності питної води, а також вплив води на якість харчових продуктів. Показано перевагу води як джерела поповнення організму біогенними речовинами.

Проаналізовано новий підхід до иілеспрямованої зміни фізико-хімічних та біологічних властивостей води шляхом безреагентного (фізичного) впливу на воду різними фізичними чинниками. Показано, щьо при цьому, без будь-яких змін ї̈ хімічного складу, фізично змінена вода здатна набувати нового квазінерівноважного термодинамічного стану, пов'язаного з накопиченням молекулами води надлишкової вільної енергії. За рахунок останньої, після припинення фізичної дії на воду, може виконуватися робота (включаючи біологічну) в тих середовищах, до яких вода входить. Показано особливість використання безреагентно модифікованої (активованої) води як компонента водних середовищ у харчових технологіях. Наведено численні приклади успішного впровадження електрохімічно активованої води (аноліту та католіту) в різноманітних галузях харчових виробнищтв та одержаний від иъього техніко-економічний, екологічний ефект і покращення якості продукції.

Ключові слова: вода, жива матерія, окисно відновний потенціал.

Постановка проблеми. За сучасними уявленнями, вода $є$ структурноенергетичною основою живої матерії, а тому питна вода, вкрай необхідна для підтримки життєдіяльності, набуває статусу головного продукту харчування. За біоритмічною шкалою поповнення організму критично важливими біогенними чинниками пиття води знаходиться посередині між ритмом дихання та ритмом вживання їжі. Але вода є також неодмінним компонентом переважної кількості харчових продуктів, а іiі хімічний склад і фізико-хімічні 
властивості суттєво впливають як на процеси виготовлення харчових продуктів, так і на їх якість (біологічну цінність), терміни зберігання і, врешті, певним чином впливає на техніко-економічні й екологічні показники харчових виробництв.

Основними вимогами до якості води як сировинного компоненту харчових продуктів є норми Держстандарту [1]. В останній редакції ДСанПіН 2.2.4171-10 від 19.09.2011 додано нові принципово важливі показники фізіологічної повноцінності мінерального складу питної води. Для дев'яти показників загальної жорсткості й лужності та сухого залишку, а також вмісту йоду, калію, кальцію, натрію, магнію та фторидів - встановлено мінімально припустиму норму вмісту в питній воді, що означає визнання особливої біологічної цінності для здоров'я людини наявності цих інгредієнтів у питній воді як важливого джерела поповнення організму.

Якість харчових продуктів пов'язана 3 фізіологічною повноцінністю води, хоча специфіка виробництва накладає свої галузеві нормативні корективи щодо якості води як складової харчової продукції. Хімічне та гігієнічне поняття «чиста питна вода» не тотожні. 3 хімічного погляду бідистилят наближається до уявлення про абсолютно чисту воду. Але гігієнічний підхід визначає таку воду як фізіологічно неповноцінну. Важливість питної води як джерела поповнення організму біогенними макро- та мікроелементами полягає в тому, що засвоєння їх з води значно ефективніше, ніж із їжі. Так, засвоєння 3 їжі залежить від активності відповідних ферментів, яка змінюється 3 віком, а також від ряду причин, які визначаються фізіологічним станом організму.

При готуванні їжі у знесоленій воді екстракція поживних речовин максимальна порівняно з водою з повноцінним природним солевмістом. Якщо відвар не входить до складу готового продукту, то разом з відваром продукт втрачає екстраговані при варінні поживні речовини. I навпаки, ми збагачуємо варений продукт, додаючи до води важливі інгредієнти [2].

Аналіз останніх досліджень і публікацій. Сучасна фізика води відкрила iі унікальні властивості бути приймачем, накопичувачем і транслятором енергії зовнішніх фізичних чинників на воду, які без жодної зміни їі хімічного складу здатні суттєво змінювати структурно-енергетичний стан води, переводячи їі з термодинамічно рівноважного стану у стан квазінерівноважний [3]. Коли молекули води повертаються до рівноважного стану, віддаючи при цьому надлишок надбаної вільної енергії, вона може піти на виконання роботи (в тому числі біологічної роботи у середовищі, до якого збуджена вода входить). Якщо активована вода входить до складу технологічних середовищ харчового виробництва, то, цілеспрямовано змінюючи структурно-енергетичний стан води, ми здатні позитивно спрямовувати фізичні, хімічні, фізикохімічні та мікробіологічні процеси в харчових технологіях в напрямку їх бажаної оптимізації, за рахунок цього поліпшувати їх техніко-економічні й екологічні показники i, врешті, підвищувати якість продукції. На відміну від хімічних реагентів, активована вода, яка може набувати тотожний їм спектр кислотно-лужних та окисно-відновних станів, після завершення технологічного процесу стає звичайною водою. 
Крім основних напрямків безреагентної активації води, найбільш теоретично та емпірично розробленим є регулювання електронодонорного стану води різними фізичними методами, серед яких домінує метод електрохімічної активації води (ЕХАВ) з використанням діафрагмових електролізерів активаторів [4].

Метою дослідження $є$ узагальнення нових уявлень про воду як чутливого сенсора, накопичувача та ретранслятора різних фізичних чинників, що призводить до зміни структурно-енергетичного стану води, а також розгляд нових явищ, коли фізично змінена вода може впливати на фізико-хімічні та біологічні властивості середовищ, компонентом яких вона $\epsilon$.

Викладення основних результатів дослідження. Для ілюстрації особливостей і можливостей методу наводимо діаграму вегетативної активності мікроорганізмів в електрохімічно активованому водному середовищі в координатах ОВП та $\mathrm{pH}$. За результатами досліджень M. Lotts [5] мікроорганізми різних типів і груп живуть та розмножуються у поживних середовищах лише в певних межах величин ОВП, залежних від кислотно-лужного стану цих середовищ. Автор створював у поживному середовищі бажані коваріантні величини ОВП та $\mathrm{pH}$, добавляючи в них певну кількість особливого біметалічного грануляту типу KDF Media, до складу якого входять компоненти міді та цинку.

За межами зони, окресленої графіком з точок коваріантних значень $\mathrm{pH}$ та ОВП, вегетація мікробів не відбувається. На прикладі мікробних клітин Рrocariota змінення $\mathrm{pH}$ від кислих значень у бік нейтральної реакції середовища супроводжується розширенням діапазону значень ОВП, сумісних із вегетативною активністю кислотостійких бактерій. Дзеркальна залежність спостерігається також стосовно лужностійких культур.

Тож спрямовано регулюючи редокс-стан поживного середовища, ми здатні очікувано регулювати вегетативну активність мікроорганізмів у робочому середовищі, в тому числі в харчових мікробіологічних технологіях.

Подібні дослідження з мікробними культурами можуть бути відтворені на обладнані нової дослідницько-випробувальної модульної лабораторії водообробки (рис. 1), створеної на базі Проблемної науково-дослідної лабораторії HУXТ.

Ця технологія успішно використовується для оптимізації технологій харчового виробництва. В [5] підвищення якості пива при зменшенні собівартості процесу досягається шляхом додавання у технологічну воду аноліту та католіту, одержаних шляхом електрохімічної активації водного розчину харчової солі із розрахунку 10 г солі на один літр. У процесі пророщування солоду використовується аноліт, який додають у воду для дезінфекції зерна, а в останню замочну воду добавляють католіт. Аноліт також ефективно використовується для дезінфекційної обробки обладнання бродильних виробництв шляхом додавання католіту в миючу воду, а аноліт - у воду для ополіскування. В катодно обробленій воді в десятки разів зменшується концентрація йонів важких металів, на 50\% зменшується жорсткість води. Анодно оброблена вода є ефективним дезінфікуючим і стерилізуючим розчином універ- 
сального застосування та високої екологічної досконалості. При замочуванні в ЕХАВ спостерігається підвищення проникності оболонок зерна та прискорюється перенесення поживних речовин. Це спричиняє прискорення біологічних процесів у зерні та збільшує енергію його проростання. Рівномірна гідратація сприяє покращенню роботи гідролітичних ферментів, які легко розчиняють залишки матриці та малі крохмальні зерна. Зволоження свіжопророслого солоду перед ферментацією ЕХА водою дає змогу скоротити термін ферментації у 2-3 рази, підвищити якість ферментованого солоду.

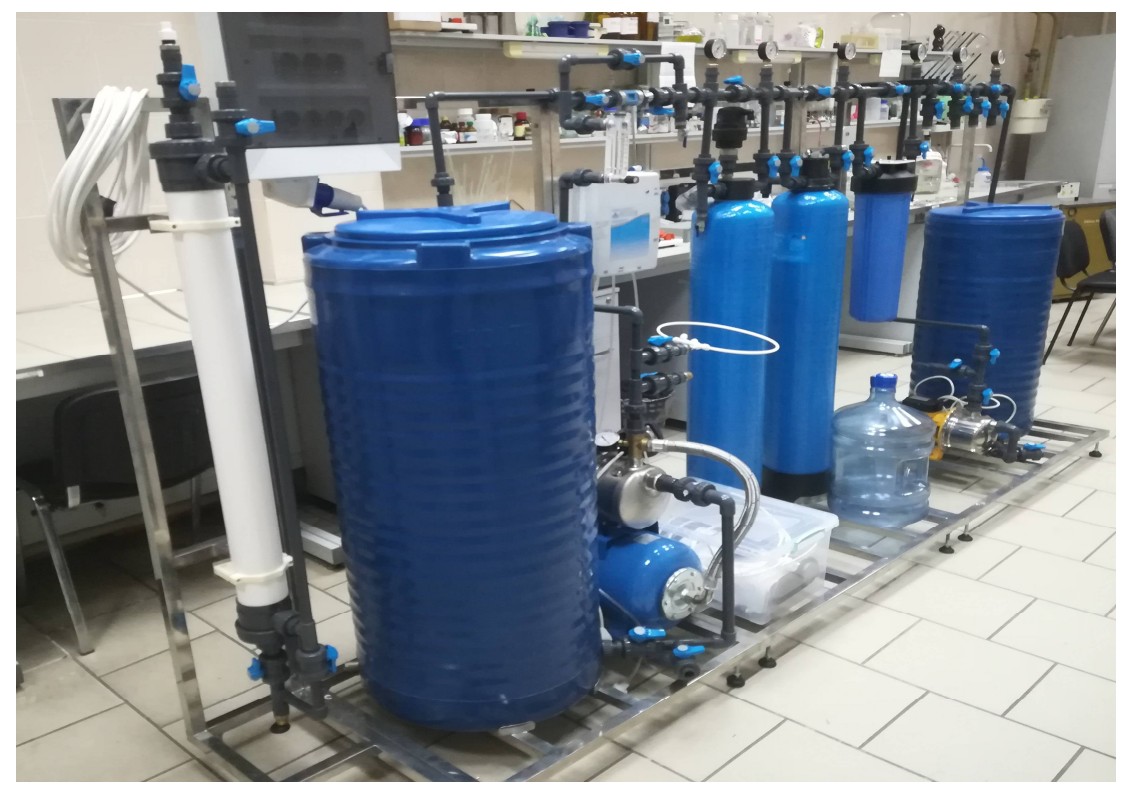

Рис. 1. Дослідницько-випробувальна модульна лабораторія водообробки

Приготування затору на ЕХАВ прискорює процес екстракції в 1,52,0 рази. Використання ЕХАВ забезпечує також високоякісну відмивку та стерилізацію будь-якого обладнання з гарантією відсутності на його поверхні мікроорганізмів будь-яких видів.

У [6; 7] розглянуто можливості використання електрохімічної активації молока з метою підвищення його окисно-відновного потенціалу і підвищення таким чином харчової цінності та збільшення терміну зберігання молочної продукції. У [8] досліджено можливість використання ЕХА води для переробки рибної та рослинної сировини. Показано, що використання ЕХА-розчинів покращує якість первинної сировини, інтенсифікує процес ферментативного гідролізу.

Досліджено позитивний вплив активованої води на якість хліба, його зберігання та безпеку вживання [9]. Показано ефективність застосування аноліту для боротьби 3 мікроорганізмами 3 метою забезпечення мікробіологічної безпеки хліба при зберіганні.

У процесі розробки безалкогольних напоїв, виготовлених 3 концентрату пивного та квасного сусла, розбавленого ЕХА водою, спостерігається інтенси- 
фікація процесів бродіння, досягається значне зростання загального числа дріжджових клітин, поліпшення їх життєздатності та бродильної активності [10].

В аналітичному огляді [11] зроблено порівняльний аналіз впливу жорсткості води, величини $\mathrm{pH}$ і ОВП середовища на м'ясні системи. Розглянуто застосування ЕХАВ як основного компоненту розсолів у виробництві м'ясних виробів, що покращує реологічні властивості м'яса, робить готову продукцію екологічно безпечною 3 набутими антиоксидантними властивостями. Вдосконалення технології виробництва емульсованих м'ясних продуктів широкого асортименту (сосиски, сардельки, варені ковбаси, тощо) наведено в [12].

Значне підвищення стабільності емульсії одержано при заміні водопровідної питної води на ЕХА, кавітаційно дезінтегровану воду, а також воду, послідовно активовану електрохімічною обробкою, а потім кавітаційним дезінтегруванням.

Встановлено [13], що додавання лужної фракції ЕХА води для посолу фаршу змінює $\mathrm{pH}$ у бік більш високих значень від ізоелектричної точки м'язових білків, що дає змогу відмовитись від використання різноманітних фосфатів, які традиційно виконують у ковбасному виробництві вищезазначену функцію.

Дослідженнями встановлено [14], що використання розчинів католіту (як у холодному, так і в гарячому стані) для миття та дезінфекції технологічного обладнання в переробці м'яса птиці не поступається за якістю миття кращим лужним і кислим хімічним засобам, дозволеним для цих цілей.

\section{Висновки}

Продовження огляду численних прикладів успішного впровадження безреагентно активованої води у харчових технологіях не вплине на вже сформоване ставлення до цього питання як вкрай важливого, актуального та цінного методу підвищення техніко-економічних показників харчового виробництва та підвищення якості продукції.

\section{Література}

1. ДСанПін 2.2.4-2.4-171-10 від 19.09.2011 р., «Гігієнічні вимоги до води, призначеної для споживання людиною». $5 \mathrm{c}$.

2. Українець А.І., Большак Ю.В., Маринін А.І. Чиста вода: еволюція критеріїв якості водопідготовка. Матеріали V Міжнародної науково-практичної конференції «Чиста вода. Фундаментальні та промислові аспекти» (26-27 жовтня 2017 р., м. Київ, Україна). C. $214-215$.

3. Антонченко В.Я., Давыдов А.С., Ильин В.В. Основы физики воды. Киев: Наукова думка, $1991.670 \mathrm{c}$.

4. Прилуцкий В.И., Бахир В.М. Электрохимически активирована вода. Аномальные свойства. Механизм биологического действия. Москва, ВНИИИНТ, 1997. 230 с.

5. Способ приготовления воды пивоваренного производства. М.И. Панова, И.А. Прыткова, Г.Д. Бесова., В.А. Назин., О.А. Брюзгина. Find Patent. RU2012. 2018.7 с.

6. Мартынова О.В. Разработка обогащенных составных молочных продуктов с применением электрохимической активации. Канд. дис. тех. наук. Орел, 2010. 192 с.

7. Влияние импульсного электромагнитного поля на жизнеспособность Escherichia coli в модельном растворе молочной сыворотки / Р.С. Святненко., А.І. Маринін., О.В. Кочу- 
бей-Литвиненко, В.Б. Захаревич. Науковий вісник Львівського начіонального університету ветеринарної медииини та біотехнологій імені СЗ Гжицького. 2016. Т. 18. № $2-$ 3(68). С $120-128$.

8. Применение ХА-растворов в биотехнологии продуктов из рыбного и растительного сырья / Р.Г. Разумовская, А.И. Кассамединов, Као Тхи Хуе, Нгуен Ван Хынг, О.В. Збродова. Вестник Астраханского государственного технического университета. 2011. № 1(51). C. $28-34$.

9. Науменко Н.В. Влияние активированной воды на формирование качества и сохранность хлеба из пшеничной муки. Канд. дис. тех. наук. Санкт-Петербург, 2007. 172 с.

10. Козлов Н.В. Разработка способа применения электрохимически активированной воды в технологии пива и безалкогольных напитков. Автореф. дисс. канд. тех. наук, Москва, 2009. 56 с.

11. Баль-Прилипко Л.В., Леонова Б.Н., Науменко Л.В. Применение активированной воды как основной составляющей рассолов для мясных изделий. Сетевой журнал «Научный результат». Серия «Технологии бизнеса и сервиса». Т. 2, № 1(7). 2016. С. 98-102.

12. Борисенко А.А., Борисенко Л.А., Подхомутов Н.В. Современные нанобиотехнологии в производстве вареных колбас. Мясные технологии. 2018. № 3. С. 56-63.

13. Применение воды с модифицированным изотопным составом и $\mathrm{pH}$ в мясной промышленности / М.Г. Барышев, С.С. Джимак, М.А. Долгов, А.С. Дыдыкин, Г.И. Касьянов. Журнал Известия высших учебных заведений. Пищевая технология. 2012. С. 63-71.

14. Абрамов К.М. Использование электроактивированной воды при переработке мяса птицы. Автореф. канд. дисс. биол. наук. Москва, 2008 г. 23 с. 